\title{
SIMULATION-BASED OPTIMIZATION OF THE POLCA ORDERING \\ SYSTEM
}

\author{
Natália Cibele De Sousa Santos \\ Federal Technological University of Paraná (UTFPR), Brazil \\ E-mail: nataliaaeng.producao@gmail.com
}

Daniel Ribeiro Gomes Postgraduation and Graduation Institute (IPOG), Brazil E-mail:daniel.gomes@gruposinagro.com.br

Jarbas Ancelmo Da Silva Júnior Federal Technological University of Paraná (UTFPR), Brazil E-mail: jarbasjunior@alunos.utfpr.edu.br

Stella Jacyszyn Bachega Federal University of Goiás (UFG), Brazil E-mail: stella@ufg.br

Dalton Matsuo Tavares Federal University of Goiás (UFG), Brazil E-mail: dalton_tavares@ufg.br

Submission: $3 / 3 / 2020$ Revision: 5/13/2020 Accept: 6/3/2020

\section{ABSTRACT}

Given an increase in consumer demand for product quality, companies need to continually improve their means of production. The use of computational resources assists companies to choose an ordering system that best suits their reality. In this sense, the present study aims to analyze and compare the performance of the Paired-cell Overlapping Loops of Cards with Authorization (POLCA) system, according to pre-established parameters in a real automobile company case, which has a flow-shop production environment. In order to do this, the research has a hypothetical-deductive scientific explanation. Also, the quantitative approach, and the experimental research procedure were employed due to the use of simulation and optimization. The computer simulation was performed using ProModel ${ }^{\circledR}$. The initial model was optimized, and the results of the two elaborated scenarios were compared. It was verified that the optimized scenario showed improvement in the average total output of the system. 
INDEPENDENT JOURNAL OF MANAGEMENT \& PRODUCTION (IJM\&P)

http://www.ijmp.jor.br

v. 12, n. 2, March-April 2021

ISSN: 2236-269X

DOI: 10.14807/ijmp.v12i2.1275

The simulation of the optimized model presented an increase in production of approximately 95.29\% when compared to the initial scenario. Nevertheless, trade-offs were verified. It is noticeable in the scenario analyzed that to increase the production of axles, the use of intermediate stocks must be increased. Finally, the present research contributes to the academic community since it proposed the study of an ordering system that has a limited number of studies, mainly in Brazil. It also contributes to the business community by encouraging the use of simulation in companies so that a better performance analysis of ordering systems can be performed prior to actual deployment.

Keywords: POLCA; simulation-based optimization; ordering systems

\section{INTRODUCTION}

Computer simulation is a technique that has been increasingly used for problem solving and decision making (SARGENT, 2010). This technique is advocated by several authors such as Buffa and Sarin (1987), Berends and Romme (1999), Chwif and Medina (2007), Freitas Filho (2008) and Law and Kelton (2000).

According to Lahiani et al. (2014), simulation has often been used by researchers for many applications in researching different topics such as productivity, introduction of new technologies, transportation, among others. However, a simple assessment does not provide enough detail for optimal decision making. Consequently, the simulation-based optimization technique is recommended to improve the performance of the studied systems. To optimize the model, an approach is proposed in which the simulation model is coupled to an optimization algorithm.

In the literature, this technique is called simulation-based optimization or simulation optimization, which is defined as an approach whereby an optimization mechanism provides input factors for the simulation program (Rogers, 2002). For Carson and Maria (1997), simulation-based optimization can be defined as the process of finding the best values for input variables among all possibilities, without explicitly evaluating each possibility. Phatak et al. (2014) also reported on the procedure.

In the context of production control are the Ordering Systems, as named by Burbidge (1983, 1990). Such systems are intended to assist in monitoring or controlling the release of production and purchase orders on the shop floor. Some of the Ordering Systems presented in the literature are the CONWIP (Constant Work in Process), TBC (Two-boundary Control), 
DOI: 10.14807/ijmp.v12i2.1275

OPT (Optimized Production Technology), Kanban, MRP (Material Requirements Planning) and POLCA (Paired-cell Overlapping Loops of Cards with Authorization), the latter being the focus system of the present article.

Computer simulation is a technique that can and is applied within production systems, including production control activities. Thus, the importance of simulation in the context of Ordering Systems is highlighted since the choice of an ordering system is extremely important for companies and the aforementioned technique can help in choosing the best ordering system for the reality of the company. Simulation applications for Ordering Systems' performance study were performed by authors such as Ghrayeb, Phojanamongkolkji and Tan (2009) and Khojasteh-Ghamari (2009) and Wang, Cao and Kong (2009). It is also possible to find in the literature several authors who used simulation-based optimization such as Bachega (2013), Bachega and Tavares (2013), Ehrenberg and Zimmermann (2012), Gansterer, Almeder and Hartl (2014) and Melouk et al. (2013).

Based on this context, the research question of the present paper is: how to apply the simulation-based optimization technique to the reality of an automobile company operating in a flow-shop production environment? Flow-shop is defined by Pinedo (2001) as a group of machines placed in series where each job follows the same processing route.

Thus, the research problem is the simulation-based optimization of the Paired-cell Overlapping Loops of Cards with Authorization (POLCA) ordering system, considering the case of an automobile company. This approach was proposed because the importance of studying a real production system applying this technique was noted so that it was possible to reduce the gap between theory and practice.

Therefore, the objective of the present article is to analyze and compare the performance of the POLCA system according to pre-established parameters in a real case that has a flowshop production environment. The present research is justified by the importance of the theme as observed in the works of Brighenti (2006), Harrell et al. (2002), Krishnamurthy and Suri (2003), Kabadurmus (2009) and Riezebos (2010). Organizations can use system simulation to find the Ordering Systems that best fits their production system to analyze and improve their performance.

\section{THEORETICAL REFERENCE}

\subsection{Simulation Based Optimization}


DOI: $10.14807 /$ ijmp.v12i2.1275

Luo and Lim (2013) define simulation-based optimization as one of the fastest growing research areas in the last two decades. Many studies have been conducted to obtain optimal or sufficient solutions for simulation-based optimization problems efficiently with limited computing efforts.

According to Carson and Maria (1997), some of the simulation software that includes special search procedures to guide a series of simulations to reveal optimal or near optimal scenarios are the ProModel ${ }^{\circledR}$, AutoMod $^{\circledR}$, Micro Saint ${ }^{\circledR}$, LayOPT ${ }^{\circledR}$ and FactoryOPT ${ }^{\circledR}$. In addition, Ólafsson and Kim (2002) state that simulation and optimization applications have become more common because different simulation software vendors have offered it as part of their simulation packages. For example, the AutoStat ${ }^{\circledR}$, OptQuest $^{\circledR}$, OPTIMIZ $^{\circledR}$, SimRunner ${ }^{\circledR}$, and WITNESS Optimizer ${ }^{\circledR}$ have already been incorporated into commercial simulation packages.

Simulation-based optimization methods can be categorized based on the nature of the problem being analyzed. Fu, Glover and April (2005) conducted a descriptive review of the main approaches to perform simulation-based optimization, as follows: i) Ranking \& Selection; ii) Response Surface Methodology - RSM (Response Surface Methodology); iii) GradientBased procedures; iv) Random Search (random search algorithms); v) Sample Path Optimization (stochastic counterpart optimization or approximation of the sample mean); vi) Metaheuristics.

The optimization module present in the ProModel ${ }^{\circledR}$ simulator software used in the present research is the SimRunner Optimization ${ }^{\circledR}$. This module consists of two features for analyzing and optimizing ProModel ${ }^{\circledR}$ simulation models. The first feature is a factorial design of experiments that reveal the effect of a change in the input factor on the objective function. The second feature is a multivariate optimization that tries various combinations of input factors to arrive at the combination that yields the best objective function value.

Harrel, Ghosh and Bowden (2000) propose steps to conduct experiments using the SimRunner ${ }^{\circledR}$, namely:

(a) Step 1: Create, verify, and validate a simulation model using the ProModel ${ }^{\circledR}$, and then create a macro that is included in the runtime interface for each input factor that is believed to influence the output of the simulation model. 
DOI: 10.14807/ijmp.v12i2.1275

(b) Step 2: Select the input factors you want to test. For each input factor, the numeric data type (integer or real) and its lower limit (lowest possible value) and upper limit (highest possible value) must be defined.

(c) Step 3: An objective function is defined to measure the utility of the solutions tested by the SimRunner ${ }^{\circledR}$. The objective function is constructed using terms extracted from the output report generated at the end of the simulation run.

(d) Step 4: The optimization profile is selected, which defines the population size of the evolutionary algorithm. Population size defines the number of solutions measured by the algorithm during each generation of your search.

(e) Step 5: Finally, the best solution found was evaluated, and the SimRunner ${ }^{\circledR}$ will inform the data of all experiments conducted and these will be classified based on their utility measured by the objective function.

\subsection{POLCA}

Faced with the growing demand for customized products worldwide, Suri (1998) developed the POLCA emission of ordering system which is part of a method also developed by Suri (1998) called Quick Response Manufacturing (QRM). POLCA was developed to serve companies operating in markets specializing in custom products which mostly operate in environments with high demand variation and require effective material control on the shop floor (Suri, 1998).

The POLCA system seeks to combine the main features of the MRP (Material Requirements Planning) and Kanban systems, thus it is classified as a hybrid system. The POLCA system has basically four characteristics according to Suri (1998):

- Material Release is performed through a system named the HL / MRP (Higher Level Material Requirements Planning).

- The control method is performed through cards, called a POLCA card, which are used for communication and control between cells.

- POLCA cards are assigned to a pair of cells instead of being specifically assigned to a product, as they do in pull production systems. If the routing of any order goes from cell $\mathrm{X}$ to cell $\mathrm{Y}$, then a POLCA $\mathrm{X} / \mathrm{Y}$ card is created and so on for the other processing steps. Working with cells in pairs makes the POLCA card ensure that one cell will only work on one task for which the target cell has available capacity. 
DOI: $10.14807 /$ ijmp.v12i2.1275

- The POLCA card, for each pair of cells, remains with the task throughout its execution through both cells and then returns to the first cell when processing in the second cell is completed, allowing the first cell to begin a new task.

Figure 1 shows a schematic representation of the operation of POLCA in a production system consisting of four sets of production cells - X, Y, Z and W cells. In the example in question, the product will be made following the X1, Y2, Z3 and W1 path.

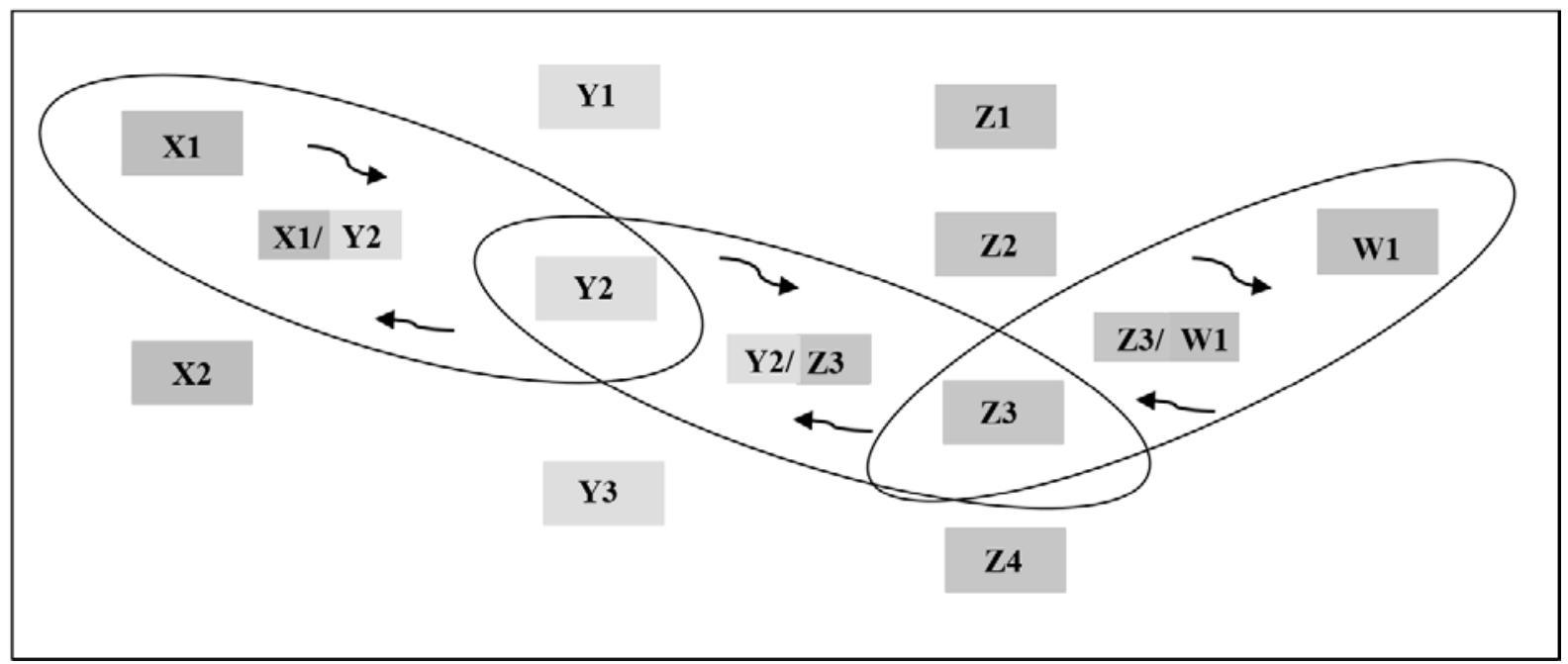

Figure 1: POLCA system operation

Source: Prepared by the authors

Referring to Figure 1, the procedure starts at the X1 Cell provided that raw material is available at X1 and a POLCA X1 / Y2 card is sequenced to the Y2 Cell. This happens sequentially for the other cards specified in this process. After a cell completes its operations, the task product and POLCA X1 / Y2 card go to the Y2 Cell input buffer, determining that further movement is required or material is available for a next operation.

Once you get to the Y2 Cell, since this task is assigned to the Z3 Cell, it is critical that you have a POLCA Y2 / Z3 card available to begin this operation. It is noteworthy that in the operation of the POLCA system the X1 / Y2 card remains with the task along the Y2 Cell along with the Y2 / Z3 card. Demonstrating that in the Y2 Cell there will be 2 cards for that particular task as part of 2 card cycles. That way each task in the Y2 Cell will carry 2 POLCA cards with it. After the completion of work in the Y2 Cell, two situations occur:

- $\quad$ The X1 / Y2 card is removed from the task and returns to the beginning of the X1 Cell;

- The task is sent to the Z3 Cell input buffer with the Y2 / Z3 card still visibly attached to the material being processed. 
INDEPENDENT JOURNAL OF MANAGEMENT \& PRODUCTION (IJM\&P)

http://www.ijmp.jor.br

v. 12, n. 2, March-April 2021

ISSN: $2236-269 X$

DOI: 10.14807/ijmp.v12i2.1275

The same process is performed for the Z3 mounting cell, which requires an available Z3 / W1 card to begin the task in the cell. Upon completion of the task, it goes to the input buffer of W1 at the same time as the Y2 / Z3 card returns to the beginning of the Y2 Cell. Since W1 is the last cell of the script, there will be no POLCA card waiting to start production and the task can be posted to W1 whenever the cell is ready to start another task. When the job in W1 is finished, it is dispatched (assuming the W Cell is a shipping cell) and card Z3 / W1 returns to the beginning of $\mathrm{Z3}$, thus completing the journey of the POLCA cards for this production order.

According to the operation described, each cell will only begin its work, except the first and last cell, if there is a card that relates the cell in question to the previous cell, and a card that relates this cell to the later cell, besides having the work authorized by the HL / MRP system according to Suri (1998). Using POLCA cards implies that cells work on tasks for which they are capable and also make sure that the back cell is capable of performing them.

According to Suri (1998), the POLCA card must clearly demonstrate the source cell and destination cell, aiming to demonstrate to workers which route should be followed. The number of POLCA cards to be used for each loop must be defined using Little's Law application. The number of cards is determined by Equation (1).

$$
N^{o} \text { of cards } A / B=\frac{L T(A)+L T(B) * N U M(A, B)}{D}
$$

LT (A) and LT (B) indicate the estimated average waiting time (in days) of the A and B Cells over the planning horizon, ie is the lead in time of the A and B Cells, respectively. Also, NUM (A, B) is the total WIP (Work in process) number that goes from the A Cell to the B Cell during the planning horizon. Finally, D represents the number of working days in the planning horizon. If the equation results in a fractional number, the result must be rounded to the next integer value.

Suri (1998) lists some advantages of using the POLCA system, such as preventing an already overloaded cell from receiving new tasks, making sure that each cell works only on tasks they are destined for, designating cells that should be able to perform them. Another advantage is that the system allows products to be produced only when there is demand for them, through the authorization of HL / MRP, avoiding unnecessary stocks.

The good performance of the POLCA was noted in some works that used simulation. Among them, Riezebos (2006) carried out experiments with models of order of arrival, demand 
INDEPENDENT JOURNAL OF MANAGEMENT \& PRODUCTION (IJM\&P)

http://www.ijmp.jor.br

v. 12, n. 2, March-April 2021

ISSN: 2236-269X

DOI: 10.14807/ijmp.v12i2.1275

variation, lot size, product mix, occurrence of malfunctions or breaks, aiming to demonstrate the effect of the number of POLCA cards on the crossing time in a productive system. It was found that the number of POLCA cards is an important measure in the project, and the simulation results showed that reducing the number of POLCA cards reduces the lead time and the number of stocks.

Kabadurmus (2009) compares the POLCA and CONWIP systems via simulation. For scenarios that were simulated, the POLCA system had better performance than the CONWIP because the CONWIP did not adapt well in environments with unstable demand and processes with high variability.

\section{METHODOLOGY}

The present research has a hypothetical-deductive scientific explanation, because from a research problem, a proposition was elaborated which was verified to be corroborated or falsified. According to Carvalho (2000), the scientific explanation of the hypotheticaldeductive type is an evolution of the deductive scientific explanation. Such evolution seeks the truth, testing the falsity of a proposition and eliminating errors (Carvalho, 2000). Thus, it is assumed that if the POLCA is adapted, it can be used in flow-shop production environments. This proposition is based on the studies by Fernandes (2007) and Stevenson, Hendry and Kingsman (2005). POLCA's proposal, according to Suri (1998), is the application in job-shop environments. The adaptation proposed in the present research aims to verify the behavior of the POLCA in a flow shop environment.

The research approach used is the quantitative one. Bryman (1989) lists some features of this approach: i) causation demonstration, presenting why things are the way they are, ii) the hypotheses to be tested present concepts that need to be meticulously measured, iii) investigations should have characteristics of replication by using the procedures employed in other studies to check the validity of the results of the first investigation.

The experimental research procedure was still employed. This procedure seeks to verify the cause and effect relationships of a given fact, and at the same time enables the researcher to manipulate the independent variables. This favors the observation of eventual changes contained in the results due to these manipulations (Creswell, 1994). According to Bryman (1989), this research procedure is more appropriate for quantitative approaches and also features mathematical modeling and computer simulations. Due to the use of simulation and optimization, this procedure was the one used in the present research. 
INDEPENDENT JOURNAL OF MANAGEMENT \& PRODUCTION (IJM\&P)

http://www.ijmp.jor.br

v. 12, n. 2, March-April 2021

ISSN: $2236-269 X$

DOI: $10.14807 /$ ijmp.v12i2.1275

The simulation was mathematical, numerical and stochastic (Law \& Kelton, 2000). According to Harrel et al. (2002), simulation can be defined as a technique of experimentation of a particular model of a real system, aiming to determine how the system will behave in face of changes made in its structure, environment, characteristics and parameters. Given the complexity of a simulation study, Law and Kelton (2000) suggest 10 steps, which helped the present study: i) Problem formulation and study planning; ii) Data collection and model definition; iii) Model validation; iv) Construction and verification of the computer program; (v) Conducting pilot executions; vi) Validation of the programmed model; vii) Design of the experiments; viii) Realization of simulation runs; (ix) Analysis of results; $x$ ) Documentation, presentation and implementation of results.

The computer simulation was performed using the ProModel ${ }^{\circledR}$ Professional SP4 software version 8.6 and the optimization was performed using the SimRunner ${ }^{\circledR}$ tool which is integrated in the simulator due to the friendly interface for the researchers and the availability for university use. To use the optimizer, the considerations of Harrel et al. (2000) were followed. As a basis for scenario design, data from a car company with flow-shop production and high production volume were used.

To guide the elaboration of the computational model, a conceptual model was made using the IDEF-SIM technique developed by Leal, Almeida and Montevechi (2008), which promotes better integration between the conceptual model and the computational model due to the use of terminologies common to the simulation area.

For the analysis of the results, a 95\% confidence level was defined and the half-width limit of up to $10 \%$ of the sample mean was established to obtain greater precision. This parameter is set by the researchers. According to Kelton, Sadowski and Sadowski (2002), in the configuration presented, 95\% of replications must be within the range of the mean achieved plus the half-range. The comparison of the scenarios was made in the Minitab ${ }^{\circledR}$ v.17 software where the paired t-test was used.

\section{RESULTS AND DISCUSSIONS}

\subsection{Characteristics of the developed scenario}

The data to perform the simulation was collected in a production line of a car company. The studied line belongs to the production of rear axles. Thus, a production order was represented in the model with seven types of axles (models), which were named axle 1 , axle 2 , axle 3, axle 4, axle 5, axle 6 and axle 7. The conceptual model is illustrated in Figure 2. 
DOI: $10.14807 /$ ijmp.v12i2.1275

The production line has five workstations (WS A through WS E), and each is tasked with doing a set of activities for assembling the shafts. For the POLCA reproduction, four POLCA card posts were placed. An initial stock (I. Stock) was also represented, in which the raw material to be used at the first workstation and throughout the process arrives at equal times established by the company. Finished axles are routed to a final stock (F. Stock), which has also been represented, plus four intermediate stocks (IS 1 through IS 4), which are used only when the next workstation is unavailable.

Thus, the entities (rear axle models) are sent to the initial stock. Therefore, when an A / B card post (CP A / B) is available at workstation A (WS A), it indicates that workstations A and B (WS B) are available for production. Production of the models is then started by sending the raw material that is in the initial stock (I. Stock) to WS A. Then, after processing at WS A, if the B / C card is available at WS B (CP B / C), the product goes to WS B, similarly to other workstations. The existence of the card next to the workstation part characterizes its processing. An axle can only be released to move to another workstation when a card for the destination station is available.

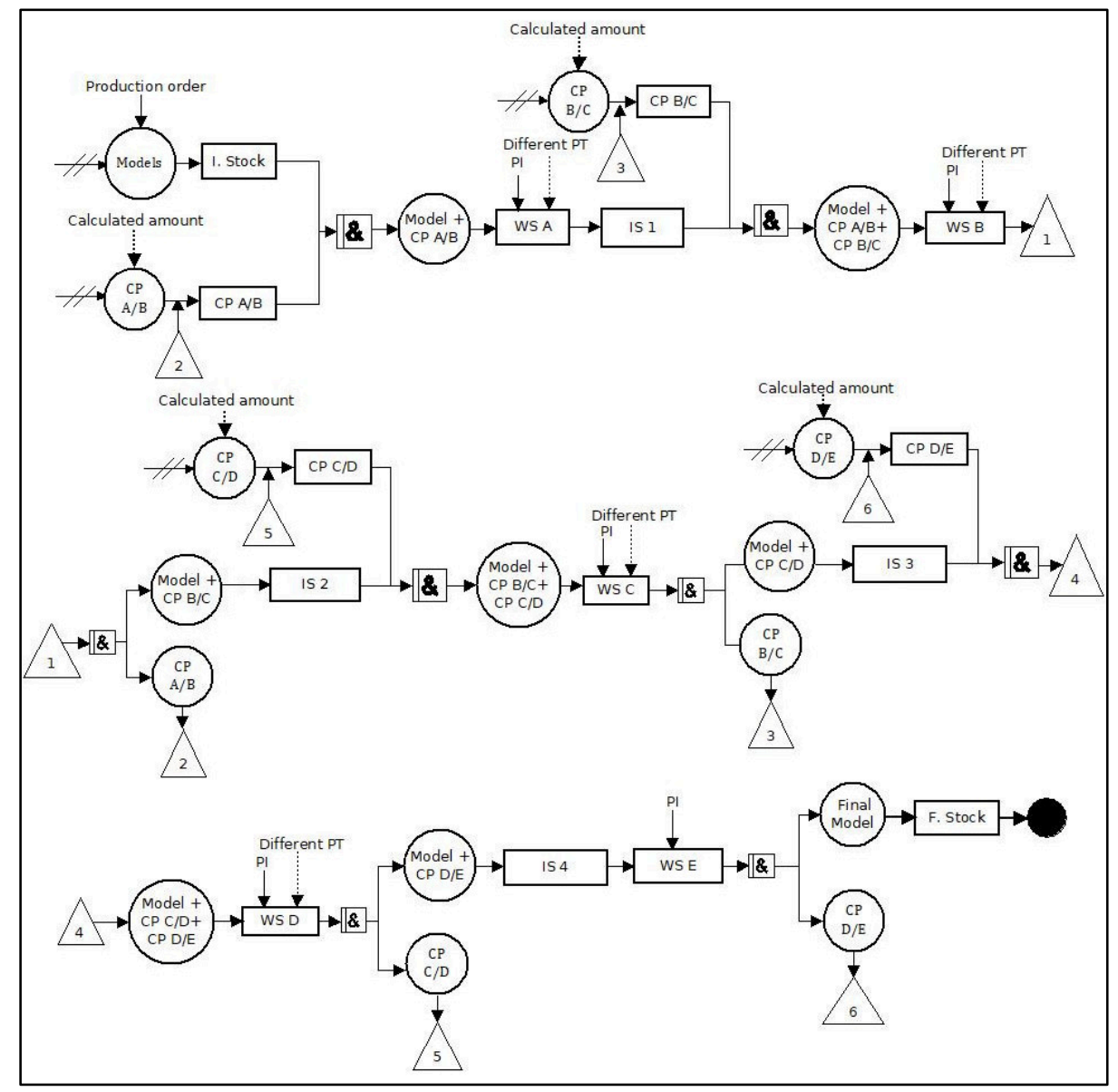

Figure 2: Conceptual model of the POLCA system Source: Prepared by the authors 
DOI: $10.14807 /$ ijmp.v12i2.1275

The time required for production is 8.63 hours, so this value symbolizes the workday in the model. Thus, the model was designed and analyzed according to the terminal system classification, and the objective of the simulated model is to examine the system performance on a normal working day following the operation of the POLCA system. Figure 3 shows an image of the ongoing simulation for the POLCA scenario.

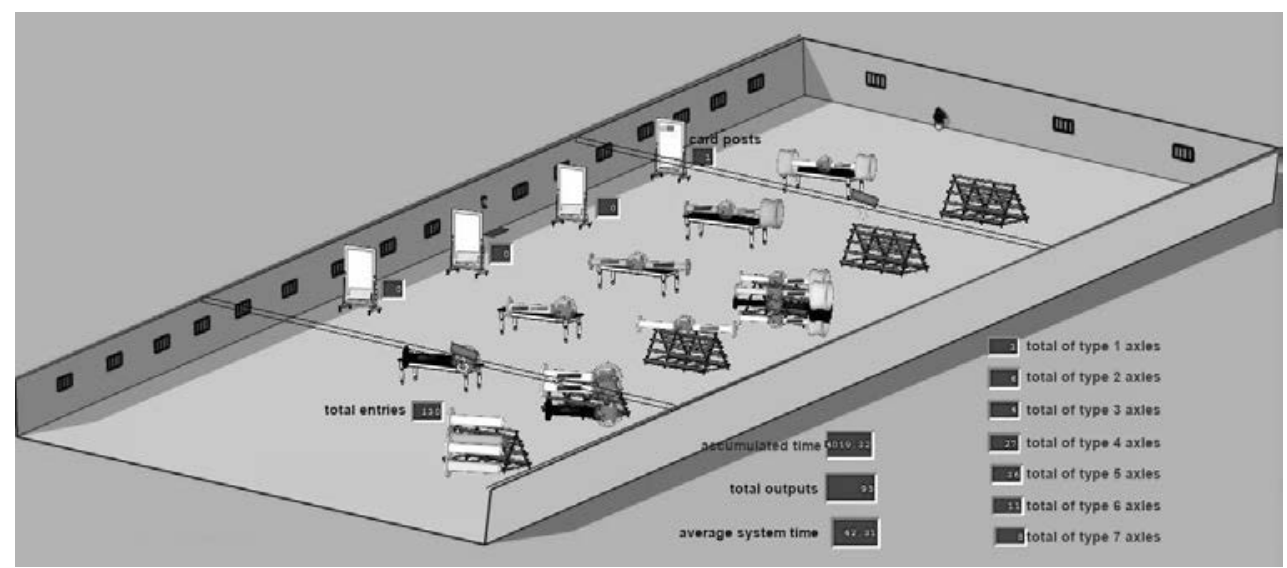

Figure 3: Simulation in progress

Source: Prepared by the authors

It should be noted that for the initial scenario (POLCA scenario adapted for a flow-shop environment), it was calculated according to Equation 1 proposed by Suri (1998), the amount of one card in each card post (CP A/B to $\mathrm{CP} D / E)$, being one $\mathrm{AB}$ card (CP A/B), one $\mathrm{BC}$ card $(\mathrm{CP} B / \mathrm{C})$, one $\mathrm{CD}$ card $(\mathrm{CP} \mathrm{C} / \mathrm{D})$ and one $\mathrm{DE}$ card $(\mathrm{CP} \mathrm{D} / \mathrm{E})$.

\subsection{Results of the POLCA scenario adapted to a flow shop environment}

Considering the results for the average production quantities of each axle type and the average total manufactured axles, due to the use of a fixed production order of the workday, the quantity reached was exactly the same in each replication. The total manufactured axles were 63 units. From the results obtained, it can be analyzed that all types of axles (from one to seven) did not show variation between the mean, maximum and minimum values because the value of the standard deviation was null for all axles.

Table 1 shows the percentage of workstation utilization. Average, maximum, minimum, standard deviation and half-width values are shown. It is observed that workstation D had the highest average utilization of $49.47 \%$ of the useful time for production. Workstation A had the lowest average utilization, with $34.21 \%$ of the working time.

The intermediate stocks were not used, which points to a positive feature of the POLCA system for the flow shop environment. Therefore, the data related to the percentage of 
INDEPENDENT JOURNAL OF MANAGEMENT \& PRODUCTION (IJM\&P)

http://www.ijmp.jor.br

v. 12, n. 2, March-April 2021

ISSN: 2236-269X

DOI: 10.14807/ijmp.v12i2.1275

utilization of intermediate stocks regarding the mean, maximum, minimum percentage, standard deviation and half-width values are zeroed.

Table 1: Workstation Utilization

\begin{tabular}{cccccc}
\hline Placement & Mean (\%) & Maximum (\%) & Minimum (\%) & Standard deviation & Half-width \\
\hline Workstation A & 34.21 & 34.75 & 33.48 & 0.34 & 0.12 \\
\hline Workstation B & 43.86 & 44.25 & 43.37 & 0.22 & 0.08 \\
\hline Workstation C & 42.02 & 42.49 & 41.42 & 0.27 & 0.1 \\
\hline Workstation D & 49.47 & 50.15 & 48.78 & 0.35 & 0.13 \\
\hline Workstation E & 38.65 & 39.21 & 38.63 & 0.11 & 0.04 \\
\hline \multicolumn{7}{c}{ Source: Prepared by the authors }
\end{tabular}

\subsection{Scenario Optimization}

For the scenario optimization reproduced in the present article, the following steps are described below:

(a) Define the variables that will influence the model responses which will be tested by the optimization algorithm: the variables defined in the present work were the number of outputs (number of axles produced) and the number of cards used at the stations to increase the number of total outputs.

(b) Determine the type of variable (real or integer) and define the lower and upper limits: the variable in the present study is the integer type, and the limits are from one to eight cards at each POLCA card post.

(c) Define the objective function that will evaluate the solutions tested by the algorithm: the purpose of the model is to optimize the production line, taking into account the improvement of the total system outputs. In the set of Equations 2 the defined objective function is described according to the language used by the SimRunner ${ }^{\circledR}$.

$$
\begin{aligned}
& \text { Entity:Max: } 1.00 * \text { axle_1 - Total Exits } \\
& \text { Entity:Max: } 1.00 * \text { axle_2 - Total Exits } \\
& \text { Entity:Max: } 1.00 * \text { axle_3 - Total Exits } \\
& \text { Entity:Max: } 1.00 * \text { axle_4 - Total Exits } \\
& \text { Entity:Max: } 1.00 * \text { axle_5 - Total Exits } \\
& \text { Entity:Max: } 1.00 * \text { axle_6 - Total Exits } \\
& \text { Entity:Max: } 1.00 * \text { axle_7 - Total Exits }
\end{aligned}
$$

(d) Define the population size of the evolutionary algorithm (this value affects the reliability and the precise time for the search management): in the population size, the cautious option was selected since it provides a large population but causes a longer time for processing. The confidence level employed was 95\%. As for the number of replications, we used the same adopted in the simulation phase, i.e. 30 replications. 
DOI: $10.14807 /$ ijmp.v12i2.1275

(e) Analyze the data according to the search performed by the optimizing algorithm.

After 542 experiments, the optimizer presented the top ten solutions which are presented in Table 2. Table 2 shows that from solution 1 to solution 5, the objective function values and the upper and lower confidence intervals remained the same, and only the number of cards available at each card post was changed. For the present research, the solution chosen for implementation in the POLCA's optimized scenario was solution 3, since the DE post had the smallest number of cards, which implies a reduction in the intermediate stock.

Table 2: Optimization values performed

\begin{tabular}{cccccccc}
\hline Solutions & FO value & $\begin{array}{c}\mathbf{N}^{\circ} \mathbf{o f} \\
\mathbf{c a r d s} \\
\mathbf{A B}\end{array}$ & $\begin{array}{c}\mathbf{N}^{\circ} \text { of } \\
\text { cards } \\
\mathbf{B C}\end{array}$ & $\begin{array}{c}\mathbf{N}^{\circ} \text { of } \\
\text { cards } \\
\mathbf{C D}\end{array}$ & $\begin{array}{c}\mathbf{N}^{\circ} \text { of } \\
\text { cards } \\
\mathbf{D E}\end{array}$ & $\begin{array}{c}\text { Lower CL } \\
\mathbf{9 5 \%}\end{array}$ & $\begin{array}{c}\text { Upper CL } \\
\mathbf{9 5 \%}\end{array}$ \\
\hline 1 & 121.667 & 5 & 3 & 6 & 7 & 121.440229 & 121.893104 \\
\hline 2 & 121.667 & 5 & 3 & 6 & 6 & 121.440229 & 121.893104 \\
\hline 3 & 121.667 & 5 & 3 & 6 & 4 & 121.440229 & 121.893104 \\
\hline 4 & 121.667 & 5 & 3 & 6 & 5 & 121.440229 & 121.893104 \\
\hline 5 & 121.667 & 5 & 3 & 6 & 8 & 121.440229 & 121.893104 \\
\hline 6 & 121.600 & 5 & 3 & 3 & 6 & 121.348104 & 121.851896 \\
\hline 7 & 121.600 & 5 & 3 & 3 & 7 & 121.348104 & 121.851896 \\
\hline 8 & 121.600 & 6 & 7 & 6 & 4 & 121.348104 & 121.851896 \\
\hline 9 & 121.600 & 5 & 3 & 3 & 5 & 121.348104 & 121.851896 \\
\hline 10 & 121.600 & 5 & 3 & 3 & 4 & 121.348104 & 121.851896 \\
\hline
\end{tabular}

\subsection{Optimized Scenario}

After the optimization, the scenario was simulated with the optimized quantity of POLCA cards at the card stations so that it was possible to make a comparative analysis of the results before and after the optimization. In the optimized scenario, we used the following number of cards: five AB cards, three BC cards, six CD cards and four DE cards. Again 30 replications were performed. The confidence semi- intervals (half-widths) found were less than $10 \%$ of the sample means, indicating that the number of replications performed in the simulation was satisfactory.

The results are shown in Table 3. The values pertaining to the average production quantities of each axle type and the average total axles produced can be observed, as well as the results of the minimum, maximum, standard deviation and confidence semi-interval (halfwidth). The average total manufactured axles were approximately 123 axles, with the largest production of type 5 axles (average of 48.93 axles). 
INDEPENDENT JOURNAL OF MANAGEMENT \& PRODUCTION (IJM\&P)

http://www.ijmp.jor.br

v. 12, n. 2, March-April 2021

ISSN: 2236-269X

DOI: 10.14807/ijmp.v12i2.1275

Table 3: Result of shaft production

\begin{tabular}{cccccc}
\hline Axle Type & Mean (\%) & Maximum (\%) & Minimum (\%) & $\begin{array}{c}\text { Standard } \\
\text { deviation }\end{array}$ & $\begin{array}{c}\text { Half- } \\
\text { width }\end{array}$ \\
\hline Axle 1 & 3 & 3 & 3 & 0 & 0 \\
\hline Axle 2 & 7 & 7 & 7 & 0 & 0 \\
\hline Axle 3 & 4 & 4 & 4 & 0 & 0 \\
\hline Axle 4 & 34 & 34 & 48.00 & 0.25 & 0.1 \\
\hline Axle 5 & 48.93 & 49.00 & 15 & 0 & 0 \\
\hline Axle 6 & 15 & 15 & 11.00 & 0.31 & 0.11 \\
\hline Axle 7 & 11.10 & 12.00 & 122 & 0.56 & 0.21 \\
\hline $\begin{array}{l}\text { Total axles } \\
\text { produced }\end{array}$ & 123.03 & 124 & & & \\
\hline
\end{tabular}

Source: Prepared by the authors

Table 4 refers to the percentage of workstation utilization. It can be verified that the $\mathrm{D}$ workstation presented the highest average use of the production time, accounting for $99.76 \%$. Meanwhile, the first workstation had the lowest average utilization, 67.93\% of the useful time for production.

Table 4: Use of workstations

\begin{tabular}{cccccc}
\hline Placement & Mean (\%) & Maximum (\%) & Minimum (\%) & $\begin{array}{c}\text { Standard } \\
\text { deviation }\end{array}$ & Half-width \\
\hline Workstation A & 67.93 & 68.70 & 67.15 & 0.38 & 0.15 \\
\hline Workstation B & 88.23 & 89.24 & 87.23 & 0.46 & 0.18 \\
\hline Workstation C & 85.17 & 86.15 & 84.44 & 0.39 & 0.15 \\
\hline Workstation D & 99.76 & 99.84 & 99.65 & 0.05 & 0.02 \\
\hline Workstation E & 76.31 & 77.07 & 75.79 & 0.28 & 0.11 \\
\hline
\end{tabular}

Source: Prepared by the authors

Table 5 refers to the percentage of utilization of intermediate stocks. Note that stocks 1 and 3 were more used. Due to the increase in cards available at the POLCA card stations, the use of intermediate stocks was expected to increase. Since the purpose of the optimized model was to maximize total system outputs, intermediate stocks were required. This fact is not a desirable feature of the original POLCA, however, in adapting to use in a flow shop system, the use of these stocks improved the system performance. It should be noted that even so, intermediate stocks had low utilization, which is a desirable feature.

Table 5: Utilization of intermediate stocks

\begin{tabular}{lccccc}
\hline Placement & Mean (\%) & Maximum (\%) & Minimum (\%) & $\begin{array}{c}\text { Standard } \\
\text { deviation }\end{array}$ & Half-width \\
\hline Intermediate stock 1 & 25.74 & 26.10 & 25.17 & 0.23 & 0.08 \\
\hline Intermediate stock 2 & 1.27 & 1.50 & 0.95 & 0.13 & 0.05 \\
\hline Intermediate stock 3 & 25.03 & 27.20 & 21.83 & 1.23 & 0.46 \\
\hline Intermediate stock 4 & 2.36 & 2.52 & 2.20 & 0.08 & 0.03 \\
\hline
\end{tabular}

Source: Prepared by the authors

\subsection{Comparative analysis between non-optimized and optimized POLCA scenarios}


INDEPENDENT JOURNAL OF MANAGEMENT \& PRODUCTION (IJM\&P)

http://www.ijmp.jor.br

v. 12, n. 2, March-April 2021

ISSN: 2236-269X

DOI: $10.14807 /$ ijmp.v12i2.1275

When comparing the results obtained in the scenarios, one can notice some differences related to their performance. Table 6 presents the values related to the average total axles produced and Table 7 shows the average times in the system.

Table 6: Comparative results regarding the average total output

\begin{tabular}{cccc}
\hline Axles & Initial scenario & Optimized scenario & Variation percentage (\%) \\
\hline Axle 1 & 3 & 3 & 0.00 \\
\hline Axle 2 & 4 & 7 & 75.00 \\
\hline Axle 3 & 4 & 4 & 0.00 \\
\hline Axle 4 & 15 & 34 & 126.67 \\
\hline Axle 5 & 23 & 48.93 & 112.74 \\
\hline Axle 6 & 7 & 15 & 114.29 \\
\hline Axle 7 & 7 & 11.10 & 58.57 \\
\hline Total axles produced & 63 & 123.03 & 95.29
\end{tabular}

Table 7: Comparative results (average time in the system)

\begin{tabular}{ccc}
\hline \multicolumn{3}{c}{ Average system time } \\
\hline Initial scenario & Optimized scenario & Variation percentage (\%) \\
\hline 21.00 mins & 45.86 mins & 118.38 \\
\hline & Source: Prepared by the authors
\end{tabular}

\section{6. $\quad$ Paired t-tests}

The paired t-test was used to compare all performance measures before and after optimization. According to Magalhães and Lima (2008), the t-test for paired samples is appropriate when there is dependence between the elements of the tested samples. In the case of the scenarios analyzed, the same workstations and the same intermediate stocks were used before and after optimization, so there is a dependency between the elements.

When making such a comparison, a hypothesis test is performed, having a null hypothesis of H0: = 0 , which states that there is no difference between the averages analyzed and the alternative hypothesis Ha: $\neq 0$, which states that there is a difference between the means that are under review. According to Devore (2006), when the p-value is lower than the significance level, being in the present research less than 0.05 , the null hypothesis is rejected.

Table 8 presents the conclusions obtained through the paired t-test. Regarding the total outputs from the initial scenario compared to the optimized one, axles 1, 2, 3 and 6 presented identical values in both columns analyzed, while axles 4, 5 and 7 are significantly different since the $\mathrm{p}$-value equals zero.

Regarding the average use of workstations, it is noted that all measures were considered statistically different in the comparisons between the initial versus optimized scenarios. Concerning the average utilization of intermediate stocks, for the comparison between the 
INDEPENDENT JOURNAL OF MANAGEMENT \& PRODUCTION (IJM\&P)

http://www.ijmp.jor.br

v. 12, n. 2, March-April 2021

ISSN: 2236-269X

DOI: 10.14807/ijmp.v12i2.1275

initial and optimized scenarios, the values are also statistically different since the p-values of all stocks are equal to zero. Regarding the average time in the system of the initial scenario compared to the optimized one, these are considered statistically different since both have pvalues equal to zero, as can be seen in Table 8 .

Table 8: Results of the paired t-test

\begin{tabular}{cc}
\hline Performance measures & Initial Scenario versus Optimized Scenario \\
\hline Axle 1 average total output & All values are identical \\
\hline Axle 2 average total output & All values are identical \\
\hline Axle 3 average total output & All values are identical \\
\hline Axle 4 average total output & Statistically different. $P$-value $=0$ \\
\hline Axle 5 average total output & Statistically different. $P$-value $=0$ \\
\hline Axle 6 average total output & All values are identical \\
\hline Axle 7 average total output & Statistically different. $P$-value $=0$ \\
\hline Average use of workstation A & Statistically different. $P$-value $=0$ \\
\hline Average use of workstation B & Statistically different. $P$-value $=0$ \\
\hline Average use of workstation C & Statistically different. $P$-value $=0$ \\
\hline Average use of workstation D & Statistically different. $P$-value $=0$ \\
\hline Average use of workstation E & Statistically different. $P$-value $=0$ \\
\hline Average utilization of intermediate stock 1 & Statistically different. $P$-value $=0$ \\
\hline Average utilization of intermediate stock 2 & Statistically different. $P$-value $=0$ \\
\hline Average utilization of intermediate stock 3 & Statistically different. $P$-value $=0$ \\
\hline Average utilization of intermediate stock 4 & Statistically different. $P$-value $=0$ \\
\hline Average system time & Statistically different. $P$-value $=0$
\end{tabular}

\section{FINAL CONSIDERATIONS}

Modeling, simulation and parameter optimization were performed in a model of the POLCA ordering system, and the best configuration was determined considering the maximization of the total system outputs. The original proposal of the POLCA system, according to Suri (1998), is to apply it in environments with job-shop production. The present work applied the POLCA system in a flow-shop production environment, which characterized an adaptation of the original system. Subsequently, the elaborated model was optimized, and the results of the two elaborated scenarios were compared. With this, the proposed objective was achieved.

The results showed that, regarding the number of axles produced, the optimized model presented a better performance. The simulation of the optimized model presented a production increase of approximately 95.29\%, compared to the initial scenario that presented, on average, 63 axles produced at the end of the work shift. In addition, the paired t-test proves the best performance of the optimized scenario since it presented statistically different results in the comparison between scenarios for the vast majority of performance measures analyzed. 
DOI: 10.14807/ijmp.v12i2.1275

However, trade-offs were verified. In the initial model there was no use of intermediate stocks and the average time of the axles in the system was lower compared to the optimized scenario that presented an average time in the system of 45.86 minutes. Thus, it can be seen in the scenario analyzed that to increase the production of axles, the use of intermediate stocks must be increased.

The present research contributes to the academic community since it proposed the study of an ordering system that has a limited number of studies, mainly in Brazil. It also contributes to the business community by encouraging the use of simulation in companies so that a better performance analysis of ordering systems can be performed prior to actual deployment.

Finally, it is recommended as future research, to simulate other Ordering Systems in different scenarios to verify and compare their behavior, as well as identify if they apply to the reality of the productive system of the company chosen for a new study.

\section{REFERENCES}

Bachega, S. J. (2013). Simulação de Sistemas de Coordenação de Ordens em Ambiente de Produção flow-shop. Thesi (PhD in Production Engineering).. São Paulo: Programa de Pós-Graduação em Engenharia de Produção (PPGEP/UFSCar)., Universidade Federal de São Carlos. 204.

Bachega, S. J., \& Tavares, D. M. (2013). Simulation-based Optimization Applied in an Automotive Company. In: INTERNATIONAL CONFERENCE ON PRODUCTION RESEARCH, 22, Foz do Iguaçu. Proceedings... Foz do Iguaçu: ICPR 22, 2013.

Berends, P., \& Romme, G. (1999). Simulation as a research tool in management studies. European Management Journal, 17(6), 576-583.

Bryman, A. (1989). Research methods and organization studies. London: Uniwin Hyman. Buffa, E. S., \& Sarin, R. K. (1987). Modern Produtction/Operations Management, 8 ed. John Wiley \& Sons.

Burbidge, J. L. (1983). Planejamento e controle da produção. São Paulo: Atlas.

Burbidge, J. L. (1990). Production Control: a universal conceptual framework. Production Planning and Control, 1(1), 3-16.

Carson, Y., \& Maria, A. (1997). Simulation optimization: methods and applications. In: WINTER SIMULATION CONFERENCE, 29, Atlanta. Proceedings... Atlanta: IEEE Computer Society, 1997. 118-126.

Carvalho, M. C. M. (2000). A construção do saber científico: algumas proposições, 2 ed. Campinas: Papirus.

Chwif, L., \& Medina, A. C. (2007). Modelagem e Simulação de Eventos Discretos: Teoria e Aplicações, 2 ed. São Paulo: Bravarte.

Creswell, J. W. (1994). Research design: qualitative \& quantitative approaches, 4 ed. London: Sage. 
Ehrenberg, C., \& Zimmermann, J. (2012). Simulation-based optimization in make-to-order production: scheduling for a special-purpose glass manufacturer. In: WINTER SIMULATION CONFERENCE, Berlin, Proceedings... Berlin: IEEE, 2012. 1-12.

Fernandes, V. O. (2007). Contribuições para o controlo da actividade de produção no sector de produção por encomenda. Thesi ( $\mathrm{PhD}$ in Production and Systems Engineering).. Portugal: Escola de Engenharia, Universidade do Minho.

Freitas Filho, P. J. (2008). Introdução à modelagem e simulação de sistemas, 2 ed. Florianópolis: Visual Books.

Fu, M. C., Glover, F. W., \& April, J. (2005). Simulation optimization: a review, new developments, and applications. In: WINTER SIMULATION CONFERENCE, Flórida, Proceedings... Flórida: IEEE, 2005. p. 13.

Gansterer, M., Almeder, C., \& Hartl, R. F. (2014). Simulation-based optimization methods for setting production planning parameters. International Journal of Production Economics, 151, 206-213.

Ghrayeb, O., Phojanamongkolkij, B., \& Tan, B. A. (2009). A hybrid push/pull system in assemble-to-order manufacturing environment. Journal of Intelligent Manufacturing, 20, 379-387.

Harrel, C., Ghosh, B. K., \& Bowden, R. (2000). Simulation using Promodel. Boston: McGraw-Hill.

Harrel, C. R. et al. (2002). Simulação: otimizando os sistemas, 2 ed. São Paulo: Belge Simulação e IMAM.

Kabadurmus, O. (2009). A comparative study of POLCA and generic CONWIP production control systems in erratic demand conditions. In: ANNUAL IIE CONFERENCE AND EXHIBITION, Norcross, Proceedings... Norcross: Institute of Industrial Engineers, 2009.

Kelton, W. D., Sadowski, R. P., \& Sadowski, D. A. (2002). Simulation with Arena, 2 ed. New York: McGraw-Hill.

Khojasteh-Ghamari, Y. (2009). A performance comparison between Kanban and CONWIP controlled assembly systems. Journal of Intelligent Manufacturing, 20, 751-760.

Krishnamurthy, A., \& Suri, R. (2003). How to Plan and Implement POLCA: A Material Control System for High-Variety or Custom-Engineered Products, Technical Report. Wisconsin, Madison: Center for Quick Response Manufacturing.

Lahiani, V. et al. (2014). Simulation based optimization approach to solve a maintenance process problem. In: CONTROL, DECISION AND INFORMATION TECHNOLOGIES, Metz, Proceedings... Metz: CoDIT, 2014. 146-151.

Law, A. M., \& Kelton, W. D. (2000). Simulation Modeling \& Analysis, 3 ed. New York: McGraw- Hill.

Leal, F., Almeida, D. A., \& Montevechi, J. A. B. (2008). Uma proposta de técnica de modelagem conceitual para a simulação através de elementos do IDEF. In: SIMPÓSIO BRASILEIRO DE PESQUISA OPERACIONAL, 50, João Pessoa, Proceedings... João Pessoa: SBPO, 2008.

Luo, Y., \& Lim, E. (2013). Simulation-based optimization over discrete sets with noisy constraints. IIE Transactions, 45(7), 699-715. 
DOI: 10.14807/ijmp.v12i2.1275

Melouk, S. H. et al. (2013). Simulation optimization-based decision support tool for steel manufacturing. International Journal of Production Economics, 141(1), 269-276.

Ólafsson, S., \& Kim, J. (2002). Simulation optimization. In: SIMULATION CONFERENCE, San Diego, Proceedings... San Diego: IEEE, 2002. 79-84.

Phatak S. et al. (2014). Simulation based optimization using PSO in manufacturing flow problems: a case study. In: WINTER SIMULATION CONFERENCE, Savannah,

Proceedings... Savannah: IEEE Press, 2014. 2136-2146.

Riezebos, J. (2006). Polca simulation of a unidirectional flow system. In: INTERNATIONAL CONFERENCE ON GROUP TECHNOLOGY/CELLULAR MANUFACTURING, 3, Groningen, Proceedings... Groningen: University of Groningen, 2006. 332-338.

Riezebos, J. (2010). Design of POLCA material control systems. International Journal of Production Research, 48(5), 1455-1477.

Rogers, P. (2002). Optimum-seeking simulation in the design and control of manufacturing systems: experience with OptQuest for Arena. In: WINTER SIMULATION CONFERENCE, San Diego, Proceedings... San Diego: IEEE, 2002. 1142-1150.

Sargent, R. G. (2010). Verification and validation of simulation models. In: WINTER SIMULATION CONFERENCE, Baltimore. Proceedings... Baltimore: IEEE, 2010. 166183.

Stevenson, M., Hendry, L.C., \& Kingsman, B.G. (2005). A review of production planning and control: the applicability of Key concepts to the make-to-order industry. International Journal of Production Research, 43(5), 869-898.

Suri, R. (1998). Quick response manufacturing: a companywide approach to reducing lead times. Portland: Productivity Press.

Wang, Y., Cao, J., \& Kong, L. (2009). Hybrid Kanban/Conwip Control System Simulation and Optimization Based on Theory of Constraints. In: INTERNATIONAL CONFERENCE ON INTELLIGENT COMPUTING AND INTELLIGENT SYSTEMS, 2, Shanghai, Proceedings... Shanghai: IEEE, 2009. 666-670. 